\title{
Antiproliferative and apoptosis inducing potential of whole plant extracts of Sesuvium portulacastrum against different cancer cell lines
}

\author{
Sathvika Chintalapani, M. S. Swathi, Mangamoori Lakshmi Narasu* \\ Centre for Biotechnology, Institute of Science and Technology, Jawaharlal Nehru Technological University, Hyderabad, India.
}

\begin{tabular}{|c|c|}
\hline ARTICLE INFO & ABSTRACT \\
\hline $\begin{array}{l}\text { Received on: } 17 / 07 / 2018 \\
\text { Accepted on: } 06 / 12 / 2018 \\
\text { Available online: } 28 / 02 / 2019\end{array}$ & $\begin{array}{l}\text { Cancer is one of the leading causes of death worldwide. Present treatment options include chemotherapy, radiation } \\
\text { therapy, and surgery, all of which have side effects. In order to mitigate the side effects of these treatments, there is } \\
\text { a need to look for combinational or alternative treatment, which is based on natural sources. Present study aims to } \\
\text { screen the whole plant extracts of Sesuvium portulcastrum for its antiproliferative activity against various cancer cell }\end{array}$ \\
\hline $\begin{array}{l}\text { Key words: } \\
\text { Sesuvium portulacastrum, } \\
\text { MTT assay, apoptosis, } \\
\text { anticancer, plant extracts. }\end{array}$ & $\begin{array}{l}\text { lines. Different extracts of } S \text {. portulacastrum were prepared using ethanol, methanol, acetone, hexane, and diethyl } \\
\text { ether as solvent. Their anticancer activity was evaluated against human breast cancer cells (MDA-MB-231), human } \\
\text { neuroblastoma cell line (IMR-32), and human colon cancer cells (HCT-116) using the } 3 \text {-( } 4,5 \text {-dimethylthiazol-2-yl)- } \\
2,5 \text {-diphenyltetrazolium bromide (MTT) assay. Propidium iodide staining method was used to observe the apoptosis- } \\
\text { associated morphological changes under the microscope. Among the five extracts, diethyl ether extract showed the } \\
\text { highest activity with IC50 values of } 288.69 \pm 6.53 \mu \mathrm{g} / \mathrm{ml} \text { for MDA-MB- } 231,231.01 \pm 6.31 \mu \mathrm{g} / \mathrm{ml} \text { for IMR-32, and } \\
182.86 \pm 4.29 \mu \mathrm{g} / \mathrm{ml} \text { for HCT-116 cell lines. Our results suggest that the extracts of } S \text {. portulacastrum exhibit good } \\
\text { anticancer activity against the different cell lines tested. }\end{array}$ \\
\hline
\end{tabular}

\section{INTRODUCTION}

Cancer is one of the leading causes of death globally. Metastasis is the major cause of death in cancer, which involves uncontrollable growth and spread of abnormal cells to other organs. Genetic defects are the causes of cancer in only 5\%-10\% of cases Anand et al., 2008. According to the world health organization, globally, one in six deaths is due to cancer and between $30 \%$ and $50 \%$ of cancers are preventable by healthy lifestyle choices.

Breast cancer refers to the abnormal growth of cells that originate in the breast tissue. They can originate from the Glandular tissues that have milk producing glands and ducts or the stromal tissue, which is a fibrous connective tissue of the breast. Worldwide, it represents $10.4 \%$ of the cancer incidences among

"Corresponding Author

Mangamoori Lakshmi Narasu, Centre for Biotechnology, Institute of Science and Technology, Jawaharlal Nehru Technological University, Hyderabad, India.E-mail: mangamoori@jntuh.ac.in women and can also appear in men (Sharma et al., 2010). It was reported that for every 12 months of breast-feeding the risk of breast cancer decreases by $4.3 \%$. It has high cure rates if diagnosed early and treated (Moller et al., 2002).

Neuroblasts are immature cells that grow into functioning nerve cells found in several areas of the body. But in neuroblastoma, a rare cancer type, neuroblasts grow uncontrollably and abnormally and form a tumor. It accounts for about $15 \%$ of all the cancer-related deaths in children and represents about $8 \%-$ $10 \%$ of all the childhood tumors (Park et al., 2010).

Colon cancer begins as a tissue growth or tissue growth on the inner lining of the colon or rectum. It is the third most common type of cancer worldwide and fourth most common cause of death. It represents $9 \%$ of all cancer occurrences (Hagger and Boushey, 2009).

Chemotherapy, radiation, surgery, and immunotherapy are often used individually or in combination to treat cancer. The chemotherapeutic agents are not only cytotoxic to tumor cells but also affect the proliferation of normal cell giving rise to side effects 
like nausea and vomiting, alopecia, and myelosuppression. In some cases, the effectiveness of cancer drugs is limited by their insolubility, instability, and low absorption in the body (Akindele et al., 2015). Further Cancer cells often develop resistance to chemotherapeutic agents that are commonly used (Kakde et al., 2011). In order to overcome these challenges, an alternative treatment, which is based on natural sources, especially from the plant kingdom is needed. Plants have a long history of use in the treatment of cancer. Also, the edible plants with anticancer properties if consumed regularly can prevent the occurrence of cancer.

Sesuvium portulacastrum L., a mangrove associate, also known as sea purslane belongs to family Aizoaceae. It is a fastgrowing, herbaceous, perennial, dichotomous, edible halophyte that grows naturally in the Mediterranean, subtropical, coastal, and warmer areas (Ramani et al., 2006). It is native to five continents Asia, Africa, Australia, South America, and North America. In India, it grows on the coastal areas of eastern and western regions (Lokhande et al., 2010).

Sesuvium portulacastrum is used as a remedy for fever, kidney diseases, and is also the best-known antidote for stings of venomous fish. It is also an important source of phytoecdysteroids (Lokhande et al., 2012). Environmentally, the plant has the ability to survive under different abiotic stress conditions like salinity, drought, and heavy metal accumulation (Slama et al., 2008). The present study aims to determine the anticancer potential of the edible medicinal plant, $S$. portulacastrum against MDA-MB-231, IMR-32, and HCT-116.

\section{MATERIALS AND METHODS}

Reagents like methanol, acetone, hexane, diethyl ether, and dimethyl sulfoxide (DMSO) were obtained from Fisher Scientific (Pittsburg, CA). RPMI-1640 medium, trypsin-EDTA (Ethylenediaminetetraacetic acid), fetal bovine serum, sodium chloride, and potassium chloride were purchased from Himedia Laboratories (Mumbai, India). Disodium hydrogen phosphate dihydrate $\left(\mathrm{Na}_{2} \mathrm{HPO}_{4} \cdot 2 \mathrm{H}_{2} \mathrm{O}\right)$ and potassium dihydrogen phosphate (KH2PO4) were obtained from Sisco Research Laboratories (SRL, Maharashtra, India). Penicillin, streptomycin sulfate, 3-(4,5-dimethylthiazol-2-yl)-2,5-diphenyltetrazolium bromide (MTT), and propidium iodide were purchased from Sigma Aldrich (St. Louis, MO).

\section{Collection of plant material}

Sesuvium portulacastrum was collected from the coastal area of Visakhapatnam, Andhra Pradesh. Plant was washed under tap water and dried in the shade to avoid thermal degradation. Dried plant was then grounded to powder and stored at a cool and dry place in dark airtight containers to avoid oxidation.

\section{Extraction}

Solvents, ethanol, methanol, acetone, hexane, and diethyl ether were used to extract the crude bioactive compounds from the plant using an orbital shaker. Initially, the plant powder was diluted with above solvents with a solvent to sample ratio of $10: 1(\mathrm{w} / \mathrm{v})$ and kept at room temperature for 24 hours. Then sample solvent mixture was kept in orbital shaker for a period of 48 hours. During this period, the bioactive compounds get extracted into the solvent system. The solvent is then filtered and concentrated under reduced pressure at $40^{\circ} \mathrm{C}$ in rotaevaporator. The concentrated extracts were dried and stored at room temperature for further analysis.

\section{Cell culture}

Human breast cancer cells (MDA-MB-231), human neuroblastoma cell line (IMR-32), and human colon cancer cells (HCT-116) were procured from NCCS, Pune. Cells were cultured in tissue culture flasks in RPMI-1640 medium supplemented with $10 \%$ fetal bovine serum, penicillin (100 IU $/ \mathrm{ml})$, streptomycin sulfate $(100 \mu \mathrm{g} / \mathrm{ml})$ at $37^{\circ} \mathrm{C}$ in a humidified incubator with $5 \%$ $\mathrm{CO}_{2}$.

\section{MTT cell proliferation assay}

In vitro cytotoxic activity of all the extracts was determined using the MTT assay as described by Manikandan et al., 2017 with slight modification. Initially, the cells were treated with $0.25 \%$ Trypsin and $0.02 \%$ EDTA in Hank's balanced salt solution for detaching them from the flask surface and making them into a single suspension. Viable cells were counted by trypan blue exclusion in a hemocytometer and diluted with the medium.

The cells were seeded in 96 well plate at a density of $1-2 \times 10^{4}$ cells per well. The plate was incubated at $37^{\circ} \mathrm{C}$ in a $5 \% \mathrm{CO}_{2}$ atmosphere. The following day media was removed and the cells were treated with standard, doxorubicin $(0.1-4 \mu \mathrm{g} / \mathrm{ml})$, and plant extracts at different concentrations $(100,200,300,400$, and $500 \mu \mathrm{g} / \mathrm{ml}$ ) for 24 hours. The extract was initially dissolved in 1:1 ratio of ethanol-ethyl acetate mixture and further diluted in medium to get the required concentrations. The final mixture used for treating the cells contained not more than $0.5 \%$ of the ethanol-ethyl acetate mixture. Negative controls were treated with the same percentage of ethanol-ethyl acetate mixture.

The treated plate was incubated at $37^{\circ} \mathrm{C}$ in a humidified incubator with $5 \% \mathrm{CO}_{2}$ for 24 hours. After the incubation period, the media was removed, $100 \mu \mathrm{l}$ of $0.1 \mathrm{mg} / \mathrm{ml}$ MTT reagent was added and incubated at $37^{\circ} \mathrm{C}$ in a humidified incubator with $5 \% \mathrm{CO}_{2}$ for 1 hour. The purple formazan crystals formed were dissolved by adding $100 \mu \mathrm{l}$ DMSO and spectrophotometric readings were taken at $540 \mathrm{~nm}$.

The cytotoxic activity of plant extract was calculated as a percentage of cell growth inhibition by using the following formula:

$$
\% \text { Growth inhibition }(\%)=\left[\frac{\left(A_{\text {Control }}-A_{\text {Sample }}\right)}{A_{\text {Control }}}\right] \times 100
$$

Where $A_{\text {control }}$ indicates the absorbance of control containing $0.5 \%$ Ethanol-ethyl acetate mixture; $A_{\text {Sample }}$ is the absorbance of treated cells at different concentration. $\mathrm{IC}_{50}$ values (the concentration of sample required for inhibition of $50 \%$ of cell growth) were obtained from the regression line.

\section{Cellular morphology analysis using phase contrast inverted microscope}

Cellular morphological changes were observed under phase contrast inverted microscope. After trypsinization, the cells were seeded in 12 well plate at a cell density of $1 \times 10^{5}$ cells per well. Following day, cells were treated with plant extracts at their respective $\mathrm{IC}_{50}$ concentrations. After 18 hours, cells were washed 
with phosphate buffered saline (PBS) and cell morphology was captured using phase contrast microscope at $100 \times$ magnification.

\section{Cellular morphology analysis by propidium iodide staining}

Propidium iodide staining was done to observe the morphological changes associated with apoptosis in the cells treated with plant extracts by the method of Rima and Mangamoori (2017) with few modifications. After trypsinization, the cells were seeded in 12 well plate at a cell density of $1 \times 10^{5}$ cells per well. Following day, cells were treated with plant extracts at their respective $\mathrm{IC}_{50}$ concentrations. After 18 hours, cells were washed with cold PBS and fixed in absolute ethanol at $4^{\circ} \mathrm{C}$ for 30 minutes. After the incubation period, ethanol was removed, PBS was added and the cells were incubated at $37^{\circ} \mathrm{C}$ in a humidified incubator with $5 \% \mathrm{CO}_{2}$ for 10 minutes. Later, $100 \mu \mathrm{l}$ of $20 \mu \mathrm{g} / \mathrm{ml}$ propidium iodide was added and photomicrographs were taken under the fluorescent microscope at $200 \times$ magnification.

\section{Statistical analysis}

All the experiments were done in triplicates and the results are expressed as mean $\pm \mathrm{SD}$. Statistical analysis was done using GraphPad Prism 7 Software. The statistical significance between the means of assays was examined by analysis of variance. $p \leq 0.05$ were considered as statistically significant.

\section{RESULTS}

\section{MTT cell proliferation assay}

The cytotoxic effect of different extracts of $S$. portulacastrum was evaluated against MDA-MB-231, IMR-32, and HCT-116 using MTT assay. The extracts showed a dosedependent inhibition of cell proliferation in MDA-MB-231, IMR-32, and HCT-116 cells as shown in Figures 1-3. Among all the extracts, diethyl ether extract showed the highest activity against all the tested cell lines (Table 1 ). The $\mathrm{IC}_{50}$ values for

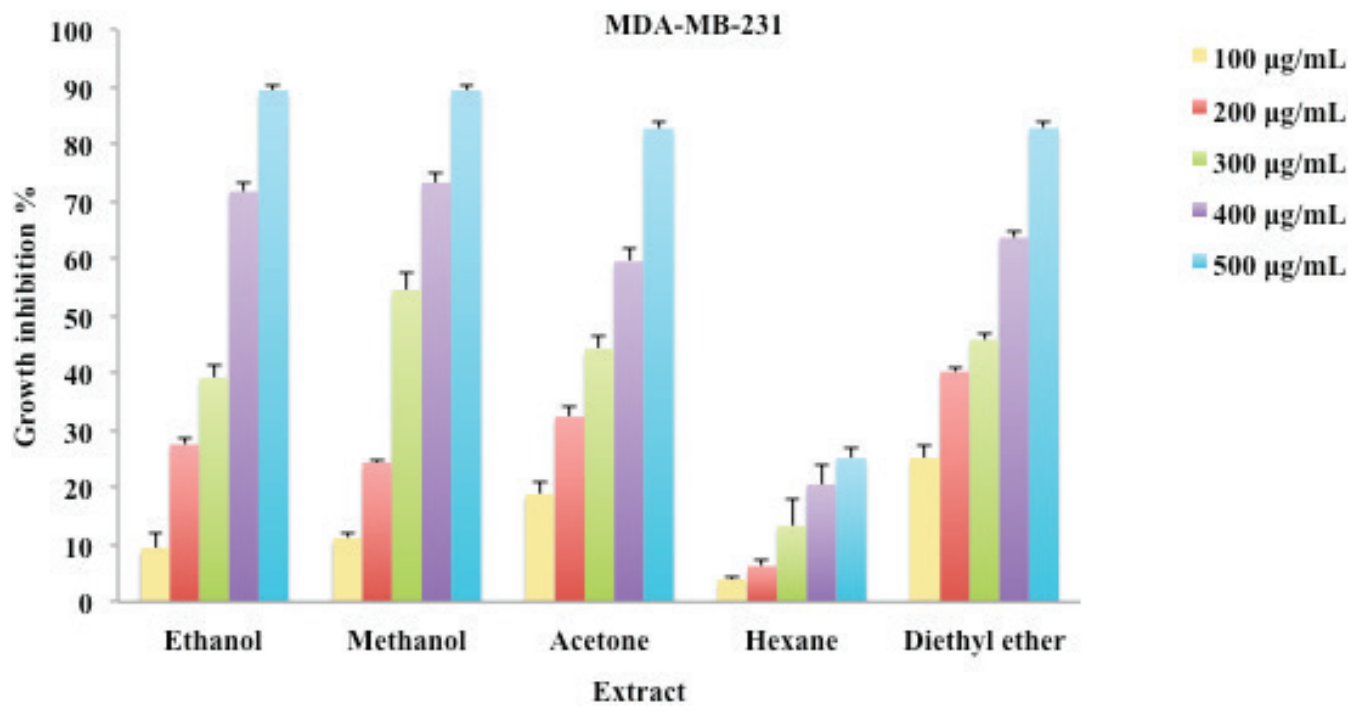

Figure 1. Cytotoxic effect of $S$. portulacastrum extracts at different concentration in MDA-MB-231 cells.

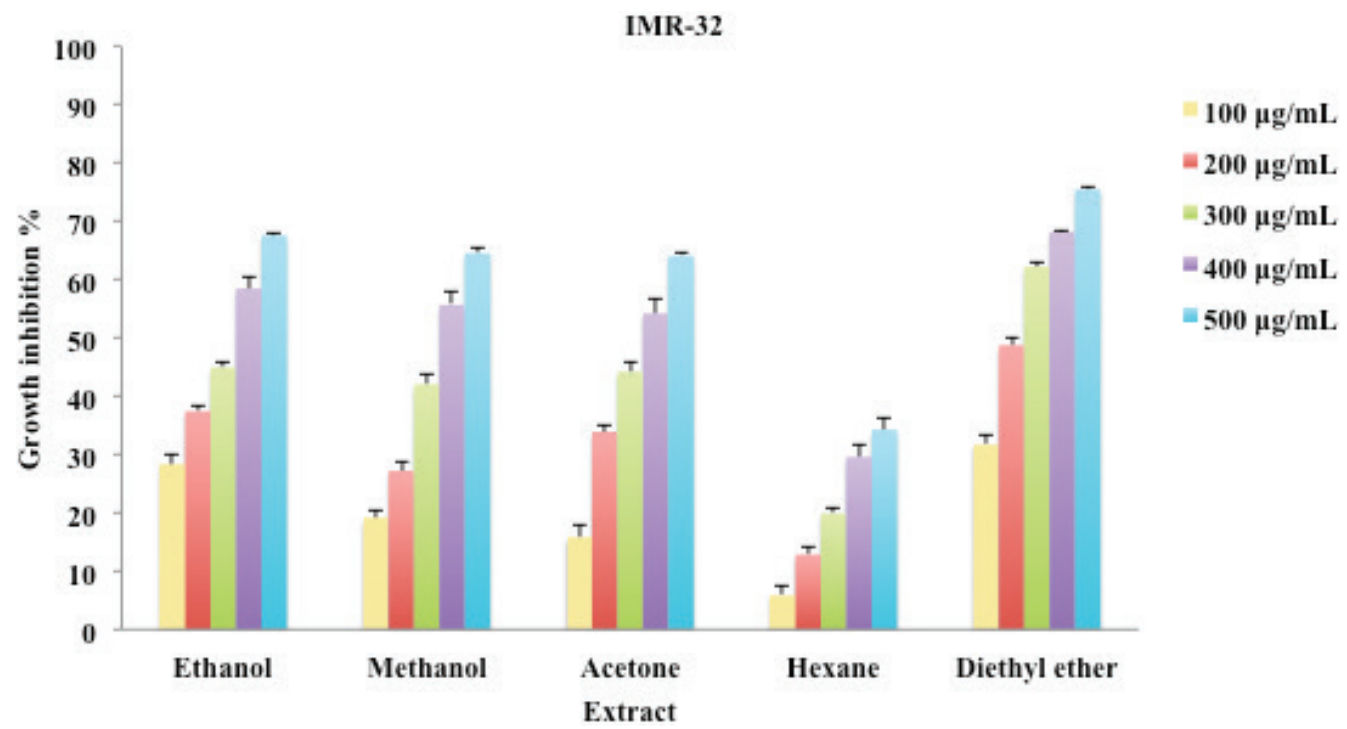

Figure 2. Cytotoxic effect of S. portulacastrum extracts at different concentration in IMR-32 cells. 


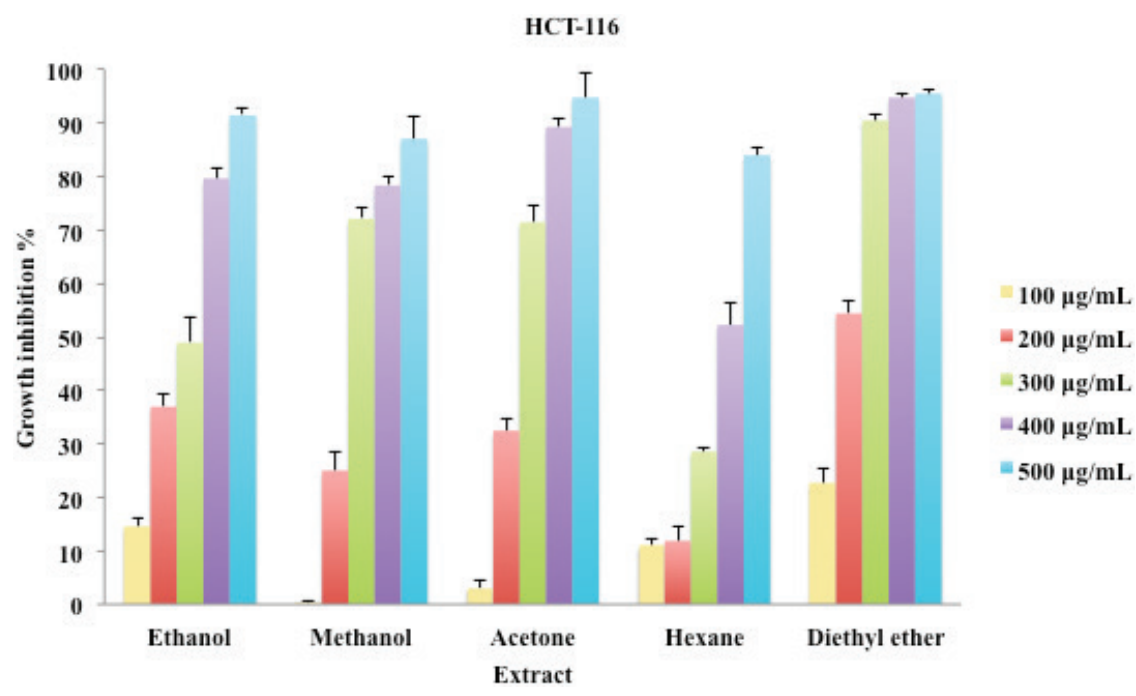

Figure 3. Cytotoxic effect of $S$. portulacastrum extracts at different concentration in HCT-116 cells.

Table 1. $\mathrm{IC}_{50}$ values of extracts of S. portulacastrum and doxorubicin in MDA-MB-231, IMR-32, and HCT-116 cells.

\begin{tabular}{lccc}
\hline \multirow{2}{*}{ Extract/Standard } & \multicolumn{3}{c}{ IC $_{\mathbf{5 0}}(\boldsymbol{\mu g} / \mathbf{m l})$} \\
\cline { 2 - 4 } & MDA-MB-231 & IMR-32 & HCT-116 \\
\hline Ethanol & $312.49 \pm 4.97^{\text {ap }}$ & $326.34 \pm 3.51^{\text {abp }}$ & $277.92 \pm 6.82^{\text {ap }}$ \\
Methanol & $297.21 \pm 2.02^{\text {ap }}$ & $269.18 \pm 8.45^{\text {adp }}$ & $248.86 \pm 3.18^{\text {ap }}$ \\
Acetone & $315.65 \pm 7.70^{\text {ap }}$ & $364.53 \pm 6.13^{\text {bp }}$ & $242.05 \pm 7.01^{\text {acq }}$ \\
Hexane & $942.07 \pm 74.82^{\text {bp }}$ & $703.40 \pm 31.19^{\text {cq }}$ & $407.87 \pm 0.40^{\text {br }}$ \\
Diethyl ether & $288.69 \pm 6.53^{\text {ap }}$ & $231.01 \pm 6.32^{\mathrm{dpq}}$ & $182.86 \pm 4.29^{\text {cq }}$ \\
Doxorubicin & $0.83 \pm 0.03^{\text {cp }}$ & $0.50 \pm 0.02^{\text {ep }}$ & $0.40 \pm 0.02^{\text {dp }}$
\end{tabular}

Data are mean values of triplicates and expressed as mean \pm SD. For each column, values with different letters $(a-d)$ indicate significantly different $(p \leq 0.05)$. For each row, values with different letters $(\mathrm{p}-\mathrm{r})$ indicate significantly different $(p \leq 0.05)$

diethyl ether extract were found to be $288.69 \pm 6.53 \mu \mathrm{g} / \mathrm{ml}$ for MDA-MB-231, $231.01 \pm 6.31 \mu \mathrm{g} / \mathrm{ml}$ for IMR-32, and $182.86 \pm$ $4.29 \mu \mathrm{g} / \mathrm{ml}$ for HCT-116 cells. The cytotoxicity of diethyl ether extract to HCT-116 was significantly $(p<0.05)$ higher than MDA-MB-231. Hexane extract did not show much inhibition at the tested concentrations in case of MBA-MB-231 and IMR-32 cells. From Table 1, we can observe that there is no significant difference between the activity of methanol, acetone, and ethanol in case of MDA-MB-231 and HCT-116 Cells. The cytotoxic effect of the standard drug, doxorubicin is significantly higher than all the extracts.

\section{Cellular analysis using phase contrast inverted microscope}

Phase contrast microscope was used to observe the morphological changes in the cells after treatment with the plant extracts. Figure 4 shows the morphological changes in MDAMB-231, IMR-32, and HCT-116 cells after treatment with the plant extracts at their respective $\mathrm{IC}_{50}$ concentrations. Untreated cells (control) exhibited normal cancer cell morphology. Significant morphological changes like cell shrinkage, reduction in cellular volume, increased number of floating, or dead cells were observed in the cells treated with the plant extracts.

\section{Cellular morphology analysis by propidium iodide staining}

The extracts of $S$. portulacastrum showed antiproliferative activity in all the selected cell lines. Therefore, it was evaluated whether the cytotoxic effects of $S$. portulacastrum extracts were related to their ability to induce apoptosis in cells. To confirm the apoptotic effects of plant extracts, propidium iodide stain was used to study the morphological changes in the cells under the microscope. Propidium iodide stained cells when observed under the fluorescent microscope showed morphological changes associated with apoptosis after treatment with plant extracts (Fig. 5). The arrows pointed indicates the morphological changes like nuclear condensation, shrinkage of the cell and fragmentation into apoptotic bodies, which are some of the morphological characteristics of the cells, which are undergoing apoptosis.

\section{DISCUSSION}

Bioactive compounds were extracted from $S$. portulacastrum using five solvents with different polarities that are ethanol, methanol, acetone, hexane, and diethyl ether. Evaluation of apoptosis in different cells treated with plant extracts was 


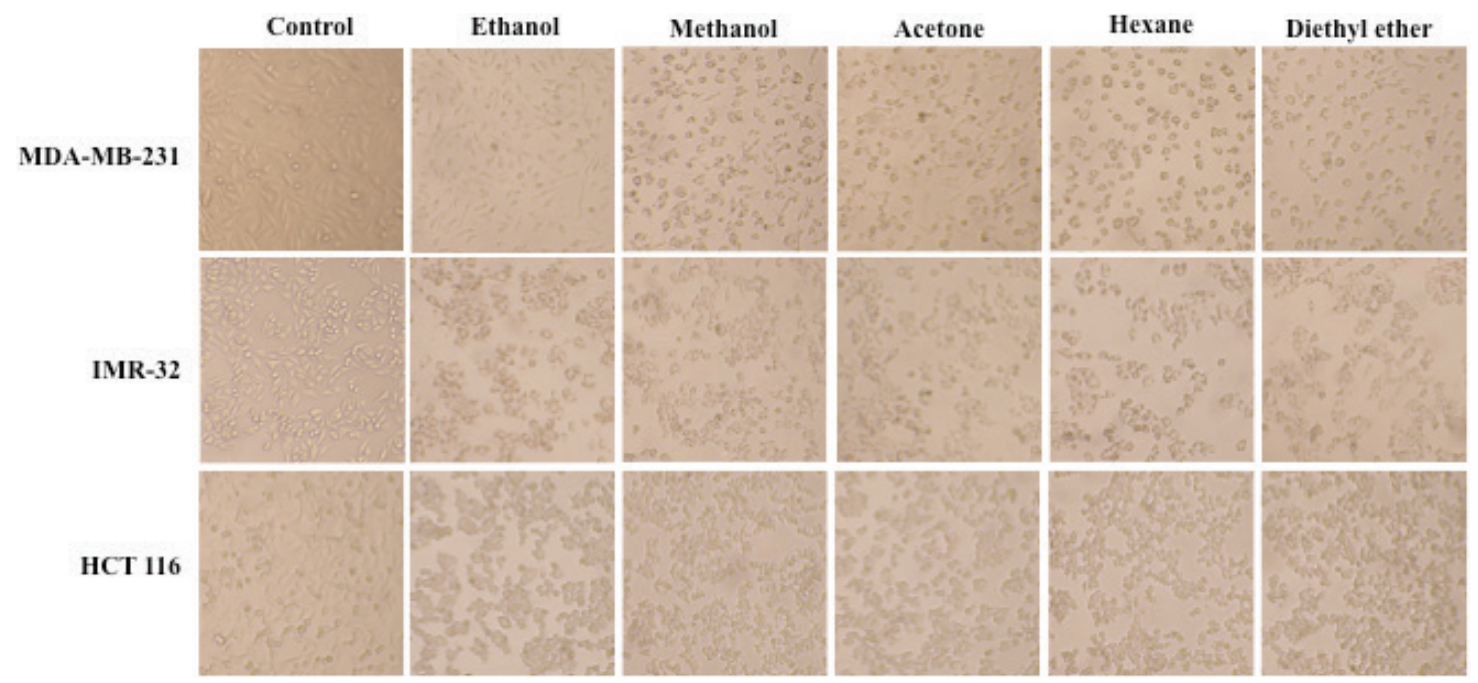

Figure 4. Morphological changes in MDA-MB-231, IMR-32, and HCT-116 cells exposed to $\mathrm{IC}_{50}$ concentrations of S. portulacastrum extracts.

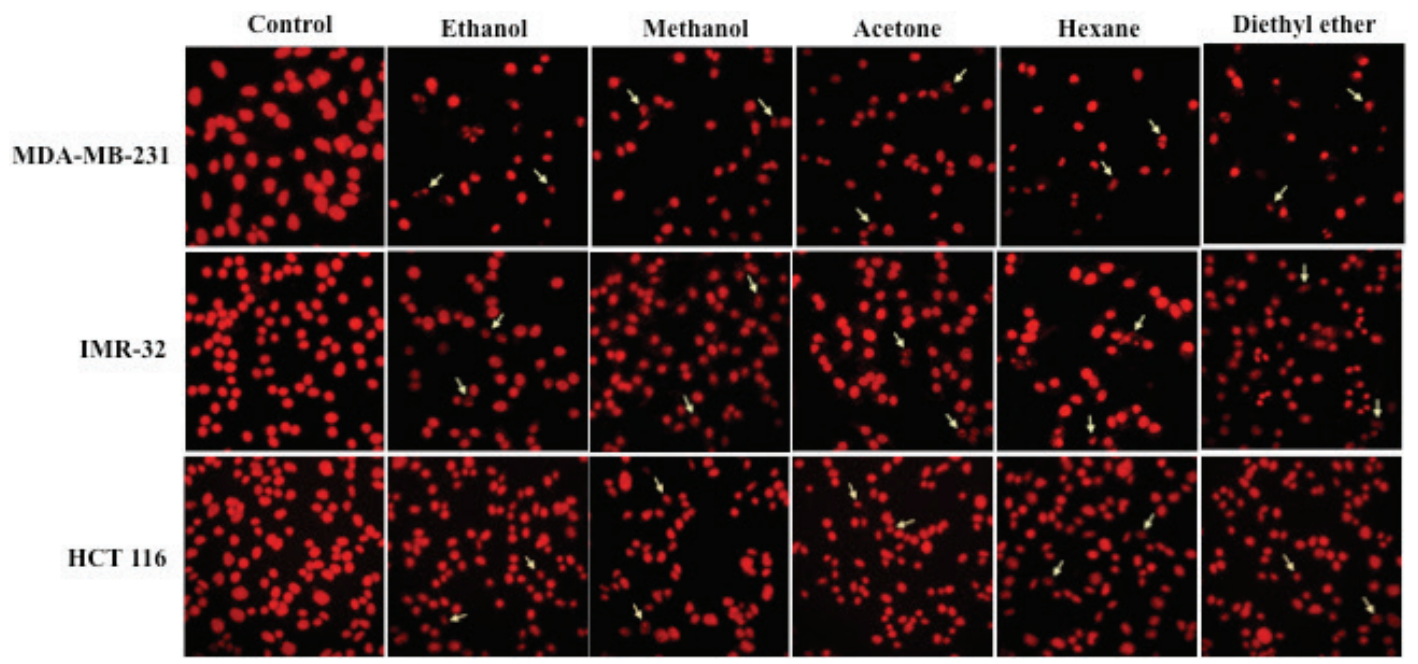

Figure 5. Morphological changes in propidium iodide stained MDA-MB-231, IMR-32, and HCT-116 cells exposed to $\mathrm{IC}_{50}$ concentrations of $S$. portulacastrum extracts.

carried out by staining the cells with a fluorochrome, propidium iodide and observing their morphology under the microscope. It is based on the principle that apoptotic cells are characterized by shrinkage of the cell, condensation of chromatin, and loss of membrane integrity (Elmore, 2007).

To my knowledge, this is the first study on in vitro anticancer activity of whole plant extracts of $S$. portulacastrum. All the five extracts of $S$. portulacastrum showed concentrationdependent growth inhibition on MDA-MB-231, IMR-31, and HCT-116 cells by induction of apoptosis.

Previous reports suggested that the phytochemical screening of $S$. portulacastrum revealed the presence of many biologically important classes of phytochemicals like alkaloids, carbohydrates, cardiac glycosides, flavonoids, phenols, saponins, sterols, terpenoids, quinones, and diterpenes (Chintalapani et al., 2018). These phytochemicals are reported to poses many biological and therapeutic properties including anticancer (Nyamai et al., 2016). It was also reported that the methanol extract of the whole plant of
S. portulacastrum showed significant antitumor activity on Ehrlich Ascites carcinoma bearing mice (Sheela and Kalavathy, 2017).

All the five extracts of $S$. portulacastrum showed concentration-dependent growth inhibition on MDA-MB-231, IMR-31, and HCT-116 cells by induction of apoptosis. Diethyl ether extract showed lower IC50 value compared with other extracts against all the cell lines. The hexane extract showed less effect on growth inhibition of MDA-MB-231, and IMR-32 cells at the tested concentrations. This variation in solvent-based cytotoxic activity can be attributed to the extraction of bioactive compounds differently in different solvents based on their polarity. The compound that is active against different cell lines could be extracted more into the diethyl ether solvent. Therefore, diethyl ether extract showed the highest activity than other solvent extracts. The gas chromatography analysis of methanol extract of $S$. portulacastrum revealed the presence of a compound, Hentriacontane, a saturated hydrocarbon. Hentriacontane has also been isolated from spinach leaves and was shown to have antitumor activity (Kumar et al., 2014). 


\section{CONCLUSION}

Our results suggest that all the extracts of $S$. portulacastrum showed dose-dependent anticancer activity against MDA-MB-231, IMR-32, and HCT-116 cell lines. Among all the extracts, diethyl ether extract showed the highest activity against all the tested cell lines. Further work has to be done to isolate, identify, and characterize the bioactive compound from the crude diethyl ether extract that is responsible for the antiproliferative activity and study its mechanism of action.

\section{REFERENCES}

Akindele AJ, Wani ZA, Sharma S, Mahajan G, Satti NK, Adeyemi OO, Mondhe DM, Saxena AK. In vitro and in vivo anticancer activity of root extracts of Sansevieria liberica Gerome and Labroy (Agavaceae). Evid Based Complementary Altern Med, 2015; 2015:1-11.

Anand P, Kunnumakara AB, Sundaram C, Harikumar KB, Tharakan ST, Lai OS, Sung B, Aggarwal BB. Cancer is a preventable disease that requires major lifestyle changes. Pharm Res, 2008; 25(9):2097-116.

Chintalapani S, Swathi MS, Mangamoori LN. Phytochemical screening and in vitro antioxidant activity of whole plant extracts of Sesuvium portulacastrum L. Asian J Pharm Clin Res, 2018; 11(1):1-6.

Elmore S. Apoptosis: a review of programmed cell death. Toxicol Pathol, 2007; 35(4):495-516.

Haggar FA, Boushey RP. Colorectal cancer epidemiology: incidence, mortality, survival, and risk factors. Clin Colon Rectal Surg, 2009; 22(04):191-7.

Kakde D, Jain D, Shrivastava V, Kakde R, Patil AT. Cancer therapeutics-opportunities, challenges and advances in drug delivery. J App Pharm Sci, 2011; 1(9):1-10.

Kumar A, Kumari PS, Somasundaram T. Gas chromatographymass spectrum (GC-MS) analysis of bioactive components of the methanol extract of halophyte, Sesuvium portulacastrum L. Int J Adv Pharm Biol Chem, 2014; 3(3):766-72.

Lokhande VH, Nikam TD, Ghane SG, Suprasanna P. In vitro culture, plant regeneration and clonal behaviour of $S$. portulacastrum (L.) L.: a prospective halophyte. Physiol Mol Biol Plants, 2010; 16(2):187-93.

Lokhande VH, Gor BK, Desai NS, Nikam TD, Suprasanna P. Sesuvium portulacastrum, a plant for drought, salt stress, sand fixation, food and phytoremediation. A review. Agron Sust Dev, 2013; 33(2):329-48.
Manikandan M, Kannan K. Pharmacokinetic and pharmacodynamic evaluation of camptothecin encapsulated poly (methacylic acid-co-methyl methacrylate) nanoparticles. J App Pharm Sci 2017; 7(3):9-16.

Moller T, Olsson H, Ranstam J. Collaborative Group on Hormonal Factors in Breast Cancer. Breast cancer and breastfeeding: collaborative reanalysis of individual data from 47 epidemiological studies in 30 countries, including 50302 women with breast cancer and 96973 women without the disease. The Lancet, 2002; 360(9328):187-95.

Nyamai DW, Arika W, Ogola PE, Njagi EN, Ngugi MP. Medicinally important phytochemicals: an untapped research avenue Research and reviews: J Pharmacogn Phytochem, 2016; 4(1):35-49.

Park JR, Eggert A, Caron H. Neuroblastoma: biology, prognosis, and treatment. Hematol Oncol Clin North Am, 2010; 24:65-86.

Ramani B, Reeck T, Debez A, Stelzer R, Huchzermeyer B, Schmidt A, Papenbrock J. Aster tripolium L. and S. portulacastrum L.: two halophytes, two strategies to survive in saline habitats. Plant Physiol Biochem, 2006; 44(5-6):395-408

Rima T, Mangamoori LN. Zerumbone inhibits proliferation and induces apoptosis, cell cycle arrest in human colon cancer cell line, HCT15. Int J Res Appl Nat Soc Sci, 2017; 5(4):49-54.

Sharma GN, Dave R, Sanadya J, Sharma P, Sharma KK. Various types and management of breast cancer: An overview. J Adv Pharm Technol Res, 2010; 1(2):109-26.

Sheela D, Kalavathy U. Anticancer activity of methanol extract of Sesuvium portulacastrum L. whole plant against Ehrlich Ascites carcinoma. Indo Am J Pharm Sci, 2017; 4(11):4500-6.

Slama I, Ghnaya T, Savouré A, Abdelly C. Combined effects of long-term salinity and soil drying on growth, water relations, nutrient status and proline accumulation of $S$. portulacastrum. C R Biol, 2008; 331(6):442-51.

\section{How to cite this article:}

Chintalapani S, Swathi MS, Narasu ML. Antiproliferative and apoptosis inducing potential of whole plant extracts of Sesuvium portulacastrum against different cancer cell lines. J Appl Pharm Sci, 2019; 9(02):038-043. 